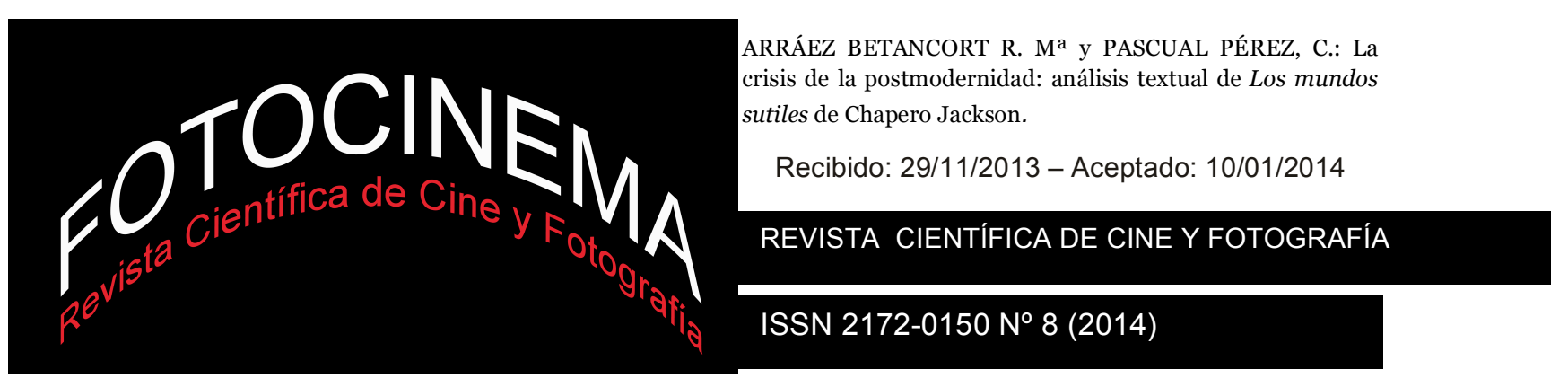

\title{
LA CRISIS DE LA POSTMODERNIDAD: ANÁLISIS TEXTUAL DE LOS MUNDOS SUTILES DE CHAPERO JACKSON
}

\section{THE CRISIS OF POSTMODERNITY: TEXTUAL ANALYSIS IN CHAPERO JACKSON'S LOS MUNDOS SUTILES}

\author{
Rosa María Arráez Betancort rarraez@uemc.es \\ Carolina Pascual Pérez cpascual@uemc.es \\ Universidad Europea Miguel de Cervantes (España)
}

\begin{abstract}
Resumen:
El cine actual genera imaginarios culturales que producen nuevos modos de mirar el mundo y que replantean su papel en el ámbito sociocultural desde los 90. Sus historias se canalizan mediante la ficción porque no encuentran su sitio en el discurso público o en la racionalidad, interviniendo en la realidad y la identidad individual y colectiva. Cómo interpretar la potencia crítica de estos creadores cinematográficos, su análisis de los problemas sociales o de la crisis postmoderna, se concreta en este artículo con el estudio de la película documental Los mundos sutiles de Eduardo Chapero Jackson sobre el poeta español Antonio Machado. Se trata de reivindicar un cine de calidad en la crisis de la postmodernidad $y$ el postmodernismo cultural, de plantear qué dice el cine sobre el mismo mundo y sobre sí mismo como fenómeno cultural que influye en la percepción de las personas y en la reconfiguración de sus expectativas.
\end{abstract}

\begin{abstract}
:
The contemporary cinema generates cultural imaginaries which give birth to new ways of contemplating the world and making cinema rephrasing its part in the sociocultural atmosphere which started in the 90's. Cinematographic stories are channeled through fiction because they don't find its place either in the public discourse or in rationality, participating at the same time in reality and in both collective and individual identity. How might we understand the criticism power of these movie makers, their vision of social problems or their interpretation of the postmodern crisis is discussed in this essay which analyzes the documentary about the Spanish poet Antonio Machado Los mundos sutiles by Eduardo Chapero Jackson who tries to advocate a quality cinema within the frame of the crisis of postmodernity and the cultural postmodernism, wondering what cinema has to say about the world and cinema itself and as a cultural phenomenon which models the perception of people and the reshaping of their expectations.
\end{abstract}

\section{Palabras clave:}

Postmodernidad; postmodernismo cultural; postmodernidad cinematográfica; crítica cinematográfica; imaginarios cinematográficos; crisis postmoderna

\section{Keywords:}

Postmodernity; cultural postmodernism; cinematographic postmodernity; cinematographic criticism; cinematographic imaginaries; postmodern crisis 


\section{Introducción y metodología: el cine como creador de imaginarios}

Autores como Lipovetsky y Serroy (2010, p.7) han calificado estos últimos años como hipermodernos, planteando el surgimiento de una nueva fase denominada hipermodernidad que ha transformado profundamente "el relieve, el sentido, la superficie social y económica de la cultura (...): se ha convertido en mundo, en cultura-mundo, cultura del tecnocapitalismo planetario, de las industrias culturales, del consumismo total, de los medios y de las redes informáticas”. Al presentar el cine estos imaginarios culturales, su papel en el ámbito sociocultural se replantea. Cómo interpretar la potencia crítica de estos creadores cinematográficos, su análisis de los problemas sociales o de la crisis postmoderna, se concreta en este artículo con el análisis textual de la película documental Los mundos sutiles de Eduardo Chapero Jackson sobre el poeta español Antonio Machado.

La recopilación bibliográfica y su estudio al respecto de la postmodernidad, la postmodernidad cultural y cinematográfica así como de la crisis que se les achaca o de la generación de imaginarios, han propiciado la elaboración de una plantilla de análisis de contenido que se ha aplicado al documental mencionado con el objeto de detectar los planteamientos específicos sobre la crisis postmoderna. Con este artículo se pretende reconocer el valor del cine, su relevancia, la importancia de su difusión como cultura, así como contribuir a la mejora de una crítica cultural también en crisis.

Dice Imbert (2013, p.15) que el cine de por sí es imaginario. También lo es el arte en general y de dos formas: por una parte, como imaginación e invención, y, por otra, como "cámara de eco del imaginario colectivo, soporte y polea de transmisión de las representaciones sociales" (Imbert, 2013, pp.15-19). Los individuos se reconocen como seres sociales mediante esas representaciones de las que habla Imbert que expresan "obsesiones, deseos y fobias" que se anclan en el inconsciente colectivo. Al arte y al cine se les atribuyen funciones miméticas y proyectivas o imaginarias. Esta última función, siguiendo a Imbert (Ibid.), alude a "un texto flotante, a veces informe, que revela estructuras profundas (de orden semántico y simbólico)”. 
El cine lo concreta tanto estética como narrativamente. Estos imaginarios sociales cinematográficos desde los 90 se canalizan mediante la ficción porque no encuentran su sitio en el discurso público o en la racionalidad, y de ese modo intervienen en la realidad y la identidad individual y colectiva. La postmodernidad cinematográfica se configura como "espacio de deconstrucción", enfrentamiento, duda y "cuestionamiento" de objetivos; como un instrumento de proyecciones más que de identificaciones.

Mediante estas proyecciones, el cine interviene en la cultura entendida como un todo, ofreciendo versiones de la realidad social al respecto de sus creencias, lenguaje común, ideas, normas, valores, símbolos, etc. Y, evidentemente, también el cine influye en la cultura como un conjunto de artes. Por una parte, porque se le ha atribuido categoría artística y, por otra, porque hace uso de otras disciplinas como la literatura, la poesía, la danza, etc. en la creación de un producto cultural final diferente a cada una de las disciplinas originales de las que parte. El cine por tanto, sería un indicador de "metaarte" en cuanto a que es una categoría artística que incluye en su esencia otras categorías artísticas diferentes. El papel del cine en la divulgación y potenciación de la cultura en general o en la postmoderna e hipermoderna en particular resulta indiscutible. Para Rodríguez Pastoriza (2006, p.16), la cultura debe ser entendida como "la producción de fenómenos que ayudan a cambiar y a transformar el sistema social”. Y el cine lo hace con películas o documentales como el que aquí se propone. De este modo, afrontar la crisis de la postmodernidad mediante el cine ayuda a entender el presente.

\section{La postmodernidad en crisis}

La crisis de la postmodernidad queda patente en los planteamientos de autores que analizan su trayectoria y el cine también contribuye a ponerla de manifiesto. Esteban (2013, p.11) afirma, siguiendo a Lipovetsky y sus planteamientos sobre el advenimiento actual de la hipermodernidad, que "la radicalización moderna de la autonomía individual ya no se expresa como 
hedonismo de superficie sino como decepción”. La llegada de la hipermodernidad se sostiene en una "cultura-mundo" basada en el consumo y en el mundo como pantalla, como característica definitoria. La pantalla global respaldada por la tecnología produce una "mutación cultural que afecta radicalmente a la creación y a la propia existencia”, siguiendo a Lipovetsky y a Serroy (Ibid.). Esta transformación cultural fruto de los avatares de la sociedad viene producida por unas causas básicamente postmodernas y los pensadores más críticos barruntan ya sus consecuencias. Pero también el cine y sus creadores como generadores de imaginarios están desempeñando un papel relevante.

Las pretensiones postmodernas de revisar críticamente los planteamientos de la Modernidad lograron la disolución de grandes modelos y principios que mantenían un orden sistemático, según Navajas (2008, p.31). Pero las características de la postmodernidad están en crisis cuando al cuestionar las aspiraciones universales de la Modernidad, se asiste a la universalidad proveniente de la cultura-mundo vehiculada por los medios de comunicación y las nuevas tecnologías comunicativas y donde se impone el mercantilismo y lo antirracional. La sociedad mediática ha traído consigo que sean los medios de comunicación los que construyan la realidad social. Como afirma Carretero (2003, pp. 94-95), los mass media actualmente sustituyen a las ideologías y a la religión de épocas pasadas para legitimar esa realidad social con lo que el poder ya no tiene el carácter represor del pasado sino que se ha convertido en seductor y "propone una simulación virtual de lo real que acaba colonizando la inteligibilidad de las diferentes esferas de la vida cotidiana”.

Del mismo modo, la postmodernidad acusa una crisis cuando al alejarse de un pensamiento ilustrado impuesto, se impone otro, cuando evitando clasificar al sujeto o imponer una idea única de sí mismo, las nuevas tecnologías y la homogeneización presentan una realidad con únicas versiones. Aludiendo a Imbert ((b) 2010, p.12), la intención de generar seres humanos autónomos no se consigue porque priman las democracias mediáticas, el relativismo y el nihilismo. El cine es reflejo de esta situación y, 
siguiendo a Imbert (2004, pp.74-75), plasma identidades difuminadas, no se distinguen los valores y se presenta un héroe negativo. Tras la muerte del sujeto, habría que hablar de la muerte de lo real, haciéndose hincapié en la relatividad de la vida y la fragilidad del mundo. En los nuevos imaginarios prima el desorden, la cultura del desastre donde violencia y muerte tienen un lugar preferente mediante una relación de ambivalencia y una fascinación por el morbo (Imbert, 2002, p.19). Beriain (2007, p.13) habla de barbarie al tolerarse una violencia destructiva, libre de justificación.

Los avances de la tecnociencia traducidos en las nuevas tecnologías de la comunicación y de la información han permitido el traspaso de las limitaciones de espacio y tiempo, originándose nuevos procesos comunicativos incidentes en la generación de una cibercultura. La supremacía de la velocidad y la necesidad de inmediatez se producen junto con el predominio de los montajes derivados de los medios de comunicación. Se esfuman los límites entre lo real y lo virtual y se ponen en duda los mecanismos de percepción sobre los que se construía la realidad en la etapa moderna. Los autores confirman la crisis al insistir en los efectos en la sociedad y en el individuo, indefensos ante una nueva discusión sobre lo real basada en parámetros aparentemente relativistas pero con una clara intención mercantil. Es lo que Imbert (2004, p.78) denomina "la lógica del show", el espectáculo cuyo objetivo es la exhibición por encima del fin histórico, llegando a una forma de desrealización que afecta, parafraseando a Llorca (2010), a la manera en que se legitima el conocimiento.

Los autores más críticos como Lyotard (1987, p.99) se cuestionan si la humanidad está capacitada para afrontar el laberinto que la rodea, al margen de las simplificaciones procedentes de las nuevas tecnologías. Simultaneidad, fragmentación y mercantilización repercuten en la posibilidad de conocer. En contraposición con el pasado y sus planteamientos, la investigación actual es fragmentaria, parcial y tentativa. Son visiones subjetivas sin intenciones de validez general, tal y como afirma Navajas (2008, p.35). La crítica de los ideales de representación, de verdad, racionalidad o coherencia, entre otros, tan característicos de teorías modernas, al igual que conceptos sobre el 
sujeto, significado y causalidad, parafraseando a Best y Kellner (1991, pp.256-298) han derivado en una crisis del papel del intelectual que ya barruntaba Ortega y Gasset al ser sustituido por el denominado sabio ignorante. De acuerdo con Imbert (2004, p.77), a la idea del binomio saber/poder, le sucede la idea de performatividad apoyada por la sociedad mediática. El héroe ha pasado a ser cualquiera que un medio haya considerado hacerle famoso. De esta manera se produce una crisis de valores, pues el reconocimiento o la fama no se consigue por "la conquista del objeto de valor sino que está cada vez más ligada a valores negativos, que consagran un héroe malo”. Como resultado, se asiste a una degradación de la cultura y a la pérdida de calidad en el arte.

Por lo tanto, las consecuencias de la postmodernidad se perciben al no prosperar su reclamo de humanización, entorpecido por las democracias mediáticas. Se asiste a una radicalización del consumismo y las relaciones sociales globales destierran lo individual. Brotan nuevos imaginarios procedentes de esos nuevos procesos comunicativos de la postmodernidad porque como plantea Barbancho (2011, p.68), la postmodernidad es "la mirada que mira a través de unas gafas deconstructivas”. Según Baudrillard (Lyon, 2000, p.41), la superioridad de los montajes afecta definitivamente la comprensión de la realidad, porque se asiste a una burla de los viejos marcadores de significados, tal y como concluye Llorca (2010). La visión tamizada de lo que ocurre impide el contacto directo con lo que se entiende clásicamente como real y este cambio sobre la percepción de lo real aqueja al conocimiento mismo, su producción y acceso. A la vez, los críticos demandan mayor reflexión desde propuestas neopositivistas o desde el positivismo reflexivo, como sucede desde el ámbito científico con Elías (2008) y Zamora (2005). Algunos autores como Lyon (2000, pp.20-22) e Imbert ((b) 2010, p.12) reclaman la ética ante el exceso de visibilización y el juego de la identidad.

Si la postmodernidad está siendo cuestionada y ha entrado en crisis, lógicamente el postmodernismo cultural padece una situación similar. La renuncia a reglas preestablecidas para reconocer una obra cultural o para 
enjuiciarla, la concepción del arte como expresión libre de cualquier deseo, la prevalencia de la mezcla de estilos o el collage mismo se produce en una sociedad de consumo donde se impone el entretenimiento y sus correspondientes industrias, huyendo de la innegable complejidad. Como plantea Muñoz de Baena (2011, pp.136-137), se trata de una industria cultural labrada a medida de ese tiempo fungible, abstracto y formalizado, copia del patrón monetario. La cultura está obligatoriamente destinada a producir conformidad y a producir productos de consumo rápido y sencillo. Frente a etapas anteriores, el público tiene una función en la producción cultural al influir en los artistas pero está considerado como mero consumidor. Calinescu (2003, p.147) critica que el arte postmoderno es gratuito, comunal, opcional y anárquico. Culpa a los artistas de renegar de la coherencia, de las ideas, de la complejidad, de la ironía, de conflictos éticos, etc., en favor de lo antirracional, apocalíptico, romántico y sentimental, e irresponsable proféticamente, según sus palabras.

Los críticos reivindican la función del arte en la crisis postmoderna, exigiendo un papel más activo en que no se huya de la complejidad para asegurar su supervivencia. Beriain (2008, pp.178-179) afirma que la creatividad "necesita tiempo libre" para su evolución en un momento en que domina la inmediatez, la velocidad..., alertando sobre el riesgo de la decadencia, de la caótica mezcla de estilos. Tras una supuesta democratización cultural se oculta la manipulación de un mercado de masas. El consumo de arte postmoderno, como menciona Olsen (1987, p.8), es un tipo de autoconsumo, una anti-creación, bien sea a través de un impulso hacia el silencio, agotamiento de la imaginación, una sensación de impotencia y entropía, o bien a través de un impulso de explosión cacofónica, una liberación de la imaginación, una sensación de improvisación fuera de control.

De acuerdo con Esteban (2013, p.11), narrar equivale a un "ejercicio de representación abstracto que se deja invadir por la memoria y que se proyecta en la imaginación”. La tensión entre la ficción y lo real se produce tanto dialéctica como dialógica y trágicamente y "va del reflejo mimético y de 
la reproducción, al intento de modificar y transformar esa realidad construida”. Siguiendo a este autor, cómo el cine influye en la memoria post o hipermoderna. O, también, de qué manera el cine refleja y transforma la realidad contemporánea mediante los imaginarios simbólicos y sociales que proyecta y produce en "el contexto de la hipervisibilidad y del consumo total”.

\section{La crisis de la postmodernidad en el cine postmoderno}

Haciendo referencia a la idea de hipercine de Serroy (Esteban, 2013, p.12), el cine estaría inmerso hoy en una cuarta etapa cinematográfica en la que se ha traspasado la propia modernidad al haberse constituido como modo de existencia. El hipercine se posiciona frente al cine procedente de la modernidad primitiva de una primera etapa. Frente a una segunda con la modernidad clásica como modelo de representación reconocible con claridad, iconicidad narrativa propia y como fenómeno industrial. Y dejando también a un lado, una tercera etapa con una modernidad vanguardista y emancipadora que cuestiona valores y estrategias de la modernidad, mediante la búsqueda de nuevas estéticas y narrativas. Este nuevo cine está carente de reglas, es una suerte de experimentación continua en cuanto a los límites del cuerpo, la identidad, lo real, lo aceptable... No es sólo una manifestación sociocultural sino que ya es la cultura y la sociedad misma. Forma parte de esa cultura-mundo ya mencionada y cabe recordar cómo Imbert (2013, p.15) analiza la capacidad del cine para producir cambios en las mentalidades, de una parte, y, de otra, como indicador de "rupturas" y "mutaciones" en la configuración de identidades sociales mediante los imaginarios que transmite.

Al tratar de establecer unos rasgos propios de las películas postmodernas, se tropieza con dificultades agravadas por las características propias de la postmodernidad, siguiendo a Zavala (2007, p.137), y conscientes de los peligros de la generalización, pueden resumirse los siguientes elementos: 
En síntesis, el cine posmoderno tiene un inicio narrativo y descriptivo acompañado por un simulacro de intriga de predestinación, la imagen tiene cierta autonomía referencial, el sonido cumple una función alternativamente didáctica, sincrónica o sinestésica, la edición es itinerante, la puesta en escena tiende a ser autónoma frente al personaje, la estructura narrativa ofrece simulacros de metanarrativa, el empleo de las convenciones genéricas y estilísticas es itinerante y lúdico, los intertextos son genéricos con algunos recursos de metaparodia y metalepsis, y el final contiene un simulacro de epifanía. Todo ello es consistente con una ideología de la incertidumbre, organizado a partir de un sistema de paradojas.

La postmodernidad afecta al cine postmoderno por la incertidumbre presente en la metanarratividad, intertextualidad y metaparodia, y por la dificultad de establecer fronteras entre distintos géneros artísticos de ficción, entre cine tradicional y cine experimental o entre cine y documental, etc. En cualquier caso, cabe también replantearse la relación entre las ficciones cinematográficas y las cotidianas, extraídas de algún modo de las películas que se ven. Los expertos reconocen la transdisciplinariedad en aras de una mayor riqueza cultural y lejos de la idea despectiva de pastiche, de la estética de pastiche como sustitución del estilo, siguiendo a Murcia (2009, pp.104105):

al contrario de lo que ocurriera con el estilo, vendría a hacer desaparecer la individualidad en aras de una canibalización aleatoria y puramente estética de los elementos formales y de contenido del pasado. La estética del pastiche, como imitación de un estilo peculiar o único y como parodia vacía, al tiempo que convierte la obra en un texto huero, hinchado gracias a la inter-textualidad, traería como consecuencia la transformación de la historia en un conjunto desfondado de imágenes y de textos... tendría que ver con el apetito social por consumir un mundo transformado en imágenes, las cuales se habrían alzado ahora como la nueva forma de reificación de la mercancía.

Transdisciplinariedad e intertextualidad sirven para dejar una huella identificativa del autor. Los textos fílmicos postmodernos son intertextuales. En ellos confluyen elementos de cultura popular y de cultura elitista, temas y valores clásicos, etc., que se revisan desde parámetros postmodernos.

El cine postmoderno parece también separarse de la tradición cinematográfica anterior, según Civila de Lara (2013, p.1) al exigir una capacidad perceptiva más activa al espectador, diferente a la que estaba 
acostumbrado, y dada la confusión de géneros, los cambios de ritmo, giros en el argumento, perspectivas diferentes, confusión entre protagonistas y antagonistas... Pero también la metanarratividad caracteriza al cine postmoderno como un intento de narrar el propio hecho de narrar, dejando constancia del proceso como un elemento de artificio del que hace uso el cine.

El fragmentarismo también caracteriza al texto fílmico al presentarse en una serie de escenas en apariencia inconexas e incluso paradójicas en las que el espectador deberá hacer el esfuerzo por darle sentido. Según Imbert, con este fragmentarismo se refleja la incertidumbre de la sociedad postmoderna sin un proceso histórico lineal y continuo que ha sido desbancado por el poder del presente, de lo simultáneo y por el carácter efímero de lo que rodea al ser humano. Como señala Zavala (2007, p.137), en los filmes postmodernos no se representa la realidad sino que ésta se presenta artísticamente mediante la ironía o la parodia que rompe con los cánones establecidos.

Los planteamientos temáticos son nuevos en cuanto a la forma de presentarse. Imbert ((a) 2010, pp.16-39) habla de "el cine como experiencia de los límites" y sintetiza algunos de estos temas y sus características por su presencia constante: el cuerpo que se mueve entre la carencia y el exceso, como elemento de culto en una lucha desesperada e inútil contra el paso del tiempo, como frontera entre la propia identidad y la relación con el otro, como expresión de sentimientos y señas del malestar contemporáneo, como reflejo de un sexo evidente e invisible indicador de una sensación de vacío que hace que el individuo se encuentre perdido, sin un proyecto de futuro. La presencia de la violencia se muestra entre lo hipervisible y lo invisible y la percepción de la realidad, que oscila entre lo ultrarreal y la fantasía. Para el cine postmoderno, el cuerpo es un elemento de comunicación crucial donde el lenguaje verbal es secundario frente a la expresión corporal.

La muerte también se presenta como una temática constante en la filmografía postmoderna y relacionada con el cuerpo y la violencia. Como plantea Imbert ((a) 2010, p.388) se consigue hacer de "la violencia un objeto recurrente e inofensivo, que satura nuestro universo de representación e 92 
incide en lo que he llamado la hipervisibilidad moderna”. Al exponer al individuo a este tipo de imágenes, su sentido de lo real queda anulado y se recrea en escenas virtuales que muestran una realidad transformada en objeto de consumo. Estas representaciones de la muerte y la violencia, desde sus distintas perspectivas se concretan en dos tendencias: el interés por una vuelta a lo primario, dejando a un lado una visión tradicional y aportando nuevas sensibilidades, que deriva en un ultrarrealismo y, por otra parte, el intento de abandonar la realidad inmediata para entrar en mundos fantasmagóricos, oníricos, que Imbert ((a) 2010, pp.559-569) denomina lo espectral. La muerte y la violencia se representan mediante una mirada extática ante la realidad y el espanto. Ambas están vinculadas al espacio en que se enmarcan, normalmente referenciando el medio urbano, que representa la soledad del individuo en la sociedad postmoderna. Estos espacios equivalen a no lugares por los que transita el sujeto sin dejar ningún rastro a su paso y se caracterizan porque indican una interconexión, son transicionales, presentan un estancamiento del tiempo, el anonimato del individuo y la pérdida de su identidad, así como espacios que favorecen la incomunicación (Imbert (a) 2010, pp.253-254). Estos no lugares son protagonistas en muchas de las novelas posmodernas: hoteles, aeropuertos, grandes ciudades, en los que las vidas de los individuos pasan desapercibidas, o en los que se favorece la creación de identidades falsas de los individuos protagonistas. Cuando se señalan estas temáticas como preponderantes en el cine, se está reconociendo la generación de imaginarios.

Entendiendo los imaginarios como un instrumento de proyecciones más que de identificaciones, cabe detenerse a considerar cómo se proyecta la literatura en el cine hiper y postmoderno, dado que la película documental analizada en este artículo: Los mundos sutiles, presenta una versión del poeta español Antonio Machado, tanto en su faceta personal como literaria. Precisamente, el continuo juego con los modelos del cine actual se refleja incluso a nivel narrativo en el reciclaje, las versiones... No se trata tanto de mimetizar o imitar al cuestionarse los modelos establecidos sino de 
deconstruir los relatos y sus héroes. El cine postmoderno expresa los límites y hace uso de elementos narrativos, frases de guiones cinematográficos anteriores sin relación con los textos originales. El mismo Pedro Almodóvar reconoce el uso que hace en sus películas de citas y referencias a otras películas clásicas y sobre todo del cine de Hitchcock, no con un fin de reconocimiento $\mathrm{u}$ homenaje a esas piezas sino con un fin puramente utilitario. Thibaudeau (2013, p. 206) recoge las siguientes palabras de Almodóvar al respecto:

Todas las películas que aparecen en las mías quedan meticulosamente escogidas, forman parte del guion en el que desempeñan un papel activo. No son homenajes sino auténticos robos, me adueño de los films en beneficio de la historia que voy contando.

El cine postmoderno hace uso de técnicas como el collage o el bricolaje para incluir diferentes referencias intertextuales. Siguiendo a Gómez (2012, pp.7788) las diferencias entre ambas técnicas radicarían en que mientras que en el collage se construye una obra a partir de fragmentos preexistentes de otras obras no necesariamente del mismo género ni disciplina artística para crear un producto diferente; en el bricolaje, la intertextualidad utilizada no queda a la vista, sólo se percibe a partir de algún paralelismo, de alguna alusión, pero de manera subterránea. Si se alude al documental Los mundos sutiles, el uso del collage más que del bricolaje, es evidente en Chapero, pues cumple con los tres elementos que según Gómez (2012, p.82) se alcanzan con el collage, “construye una determinada poética visual, es una forma de materializar la narración y a través de las citas deja abierto un campo especulativo de relaciones".

$\mathrm{Al}$ analizar películas o documentales del momento actual, puede encontrarse en ellos la mirada postmoderna del cine sobre los fenómenos literarios pasados, presentes y futuros o sobre la literatura misma. Que la literatura ha sido una fuente de inspiración y base de argumentos fílmicos es un hecho, sin embargo esto no significa que deba supeditarse la literatura al cine, sino que se trata de una influencia recíproca. Existen directores cinematográficos que en ocasiones son sus propios guionistas y crean las historias que les interesa llevar a la pantalla. Es el caso de Pedro Almodóvar, M. Armendáriz, Carlos 
Saura, Itziar Bollaín, Woody Allen, Quentin Tarantino, Alejandro Amenábar, Julio Medem, entre otros tantos. En Los mundos sutiles de Chapero-Jackson se parte de una temática literaria, que se concreta, sin embargo, en una obra original.

Al hablar de la relación entre la literatura y el cine debería valorarse la intertextualidad que se produce entre ambas disciplinas, elemento caracterizador del posmodernismo cinematográfico ya citado. Siguiendo a Peña-Ardid (2009, p.15), el nuevo texto supone "un mosaico de citas relacionado con otros enunciados homogéneos o pertenecientes a sistemas semióticos de diversa naturaleza", lo que supone que el lector/espectador podrá reconocer una serie de referencias explícitas o no, así como estructuras y lenguajes que su experiencia considera propios de un determinado sistema trasplantado a otro.

En la generación de imaginarios por parte del cine se le reconoce un papel en la divulgación y potenciación de la cultura no sólo como un arte, sino entendida como un todo. Gordon (2013) afirma, en contraposición con el arte postmoderno predominante y sus mercados, que "aún existen producciones cuyo uso del espacio y del tiempo son coherentes y están comprometidas con su propio espacio, su propio momento, y que cuyo compromiso es político, que el arte político es posible”, lejos de lo superficial y mediante imágenes que pueden cambiar el mundo. Ahondar en la película documental de Chapero-Jackson permite reconocer su particular posicionamiento postmoderno.

\section{Los imaginarios de la crisis postmoderna en Los mundos sutiles de Chapero Jackson}

SEMINCI 2012 galardonó el documental Los mundos sutiles de Eduardo Chapero Jackson. Se trata de un trabajo encargado al cineasta con motivo del centenario de la publicación de Campos de Castilla del poeta Antonio Machado. Este trabajo cinematográfico poco convencional permite la localización de ideas, temas y estéticas propias de la postmodernidad al 
reunir, fundamentalmente, poesía, danza y cine, en su guión. Chapero (Combarros, 2012) se acerca al poemario y al imaginario de Antonio Machado desde una mirada actual, buscando un modo original de plasmar el mundo interior del poeta y de la protagonista, de manera que se perciba su confluencia:

Planteamos un punto de partida que es ficción: que los estudiantes del Conservatorio Superior de Danza María de Ávila (en Madrid) tuviesen que preparar un trabajo de fin de curso sobre Machado y afrontar unas pruebas para ser seleccionados. Sira (la protagonista) tiene que empezar a leer su obra y a vincularse a ella de una forma muy personal a través de la danza. La danza nos servía para realizar una puesta en escena de algo que es tan abstracto como la poesía, tiene esa capacidad fílmica.

Sociedad y cultura postmodernas están presentes en Chapero-Jackson, aunque dejando a un lado los radicalismos inútiles. Recurriendo a Machado, en el guión de este documental se afirma: “Tomar partido no es sólo renunciar a las razones de nuestros adversarios sino también a las vuestras, abolir el diálogo, renunciar en suma a la razón humana”. Antonio Machado cede a su deseo de no mezclar poesía y política al desarrollar una conciencia social en que la poesía acaba convirtiéndose en una semilla que da sus frutos a pesar de la aridez del mundo. El cineasta y guionista (Iglesia, 2012) califica a Machado como postmoderno porque:

Machado hace una interesante defensa del ser poético (...) y lo opone al ser racional. Él creía que la razón y el ser no casan en contra de la famosa frase "pienso, luego existo". Machado sostenía que uno existe porque también siente, creía en las emociones y, en particular, en la intuición (...) el ser poético engloba lo emocional y lo intuitivo, dos formas tan ricas como el raciocinio o la lógica (...) lo poético puede llegar a tocar cosas que se escapan de la razón, lo poético puede abrazar lo global.

Chapero Jackson encuentra en la poesía lo que considera Fernández (2010, pp.3-4) que la poesía aporta al discurso posmoderno, tanto en su interior como en su contra, por un lado como una reacción contra las lacras de un ejercicio de poder incluidas en determinados discursos, y por otro lado, como un discurso que cuestiona las condiciones del saber. La poesía se presenta como una escritura que hace referencia a una serie de discursos superpuestos que llegan a reclamar un espacio más allá de la propia escritura para 
sustentar la propia historia de la tradición cultural. De este mismo modo, en Los mundos sutiles se deja constancia del acercamiento a la tradición por parte de Machado mediante lo que él denomina autofolclore o folclore de sí mismo. Y también aclara que "vivimos en un mundo esencialmente apócrifo, en un cosmos o poema de nuestro pensar ordenado o construido todo él sobre supuestos indemostrables”.

Chapero (Combarros, 2012) quiere reflejar la sociedad postmoderna al mostrar los extrarradios similares de cualquier ciudad [fig. 1]:

Se ha producido una pérdida de identidad y un anonimato enorme. Ella (la protagonista de Los mundos sutiles) crece en un entorno producto de la burbuja inmobiliaria, que es parte de esos pecados capitales que Machado retrata, como la avaricia o la envidia, pecados por otra parte muy españoles. Esa avaricia hace que como sociedad en un momento dado cada cual mire para lo suyo y se inicie una carrera por hacerse rico sin preocuparse por la sostenibilidad de aquello ni por el bien común. Y eso genera toda una serie de soledades y de crisis social y personal. Todo eso está ahí, en Machado, y descubrirlo te hace reflexionar sobre cómo en un siglo algunas cosas no han cambiado y tendemos a repetir nuestra historia colectiva. Es muy interesante que el paralelismo sea tan claro.

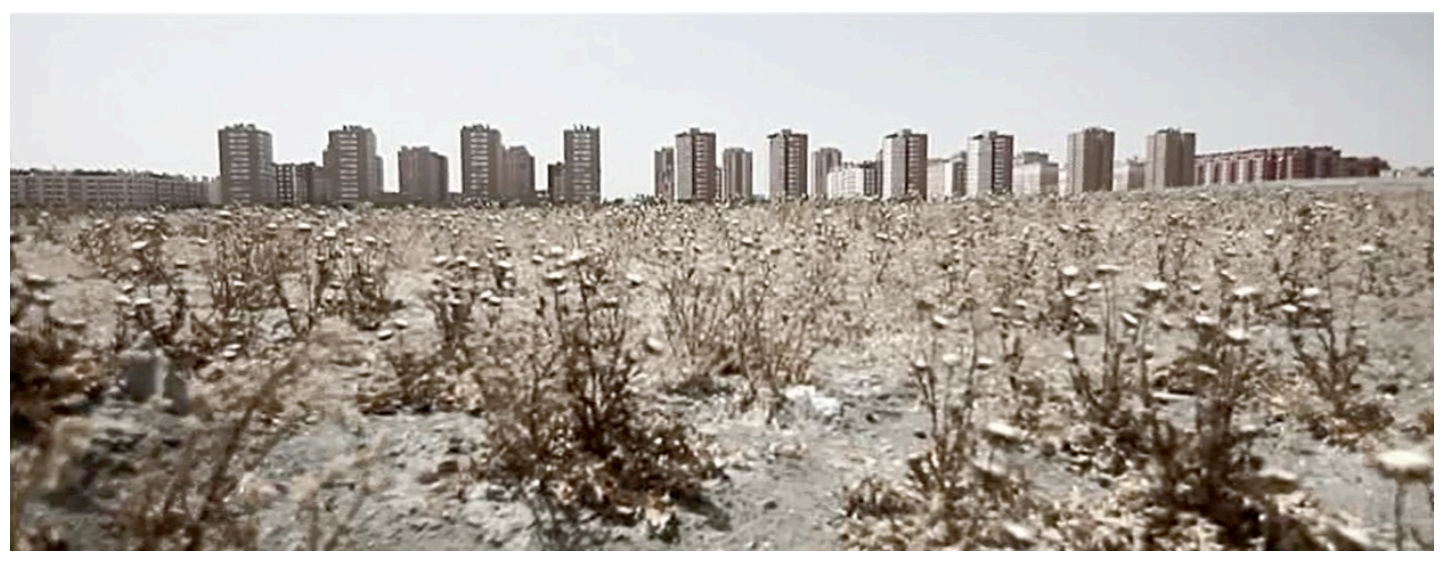

La idea de los espacios postmodernos como no-lugares por perderse en ellos la identidad del individuo, afecta a la concepción del propio cuerpo humano, concebido como señala Llorca (2005, p.240), como una porción de espacio con sus propias fronteras, "sus centros vitales, sus defensas y sus debilidades, su coraza y sus defectos”. Chapero nos da esa visión del cuerpo humano mediante la imagen final de Sira, que en el medio de ese no lugar, de ese descampado donde se desarrolla la última escena [fig. 2], ella se encuentra 
con su coraza dentro de su pompa de jabón aparentemente satisfecha consigo misma.

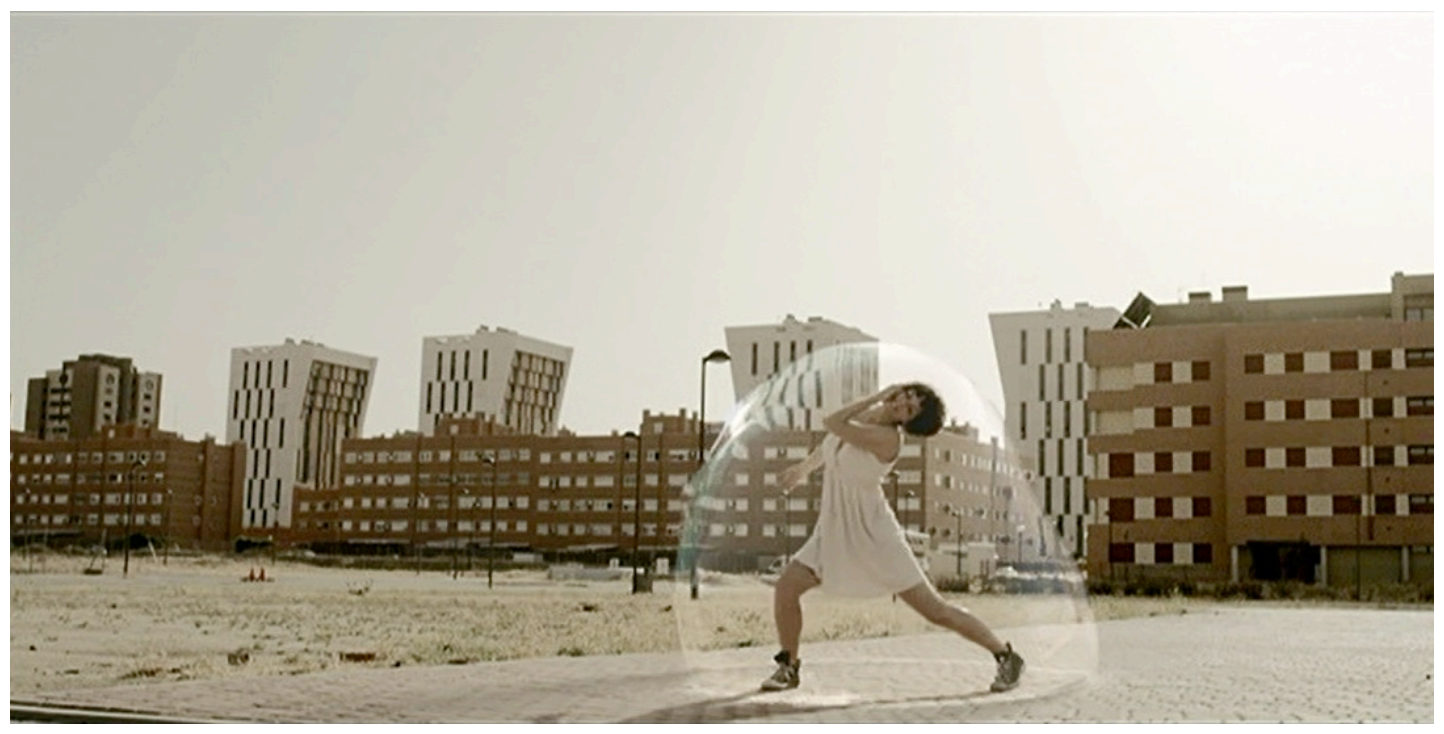

Al seleccionar para su guión cinematográfico versos de Machado como "entre el vivir y el soñar hay una tercera cosa, adivínalo", Chapero- Jackson se aleja de un nihilismo y un positivismo extremos. Tal y como afirma Navajas (1993, p.129), "la nostalgia reconoce que ese pasado no puede volver" y la nostalgia del poeta tiene un sentido de retorno a un pasado que concluye pero del que se regresa renacido. Retomando el guión de este documental: "Hemos perdido la guerra pero, humanamente, no estoy tan seguro. Quizás la hemos ganado...”. En Los mundos sutiles se produce una conexión entre el pasado, reflejado en el momento en que transcurre la obra de Machado, y el presente: "mi intención era la de extrapolar, la de hablar de los Campos de Castilla de hoy". En concreto, sobre una de sus escenas con un arado como protagonista y a modo de recreación [fig. 3], explica:

En verdad, hay algo de anacrónico en la escena. Viviendo la crisis económica que vivimos, la crudeza del campo está más cerca que nunca, estamos rodeados de ella. En esta escena, se trataba de traer al presente esa realidad, de allí que el arado sea llevado por un hombre negro, impensable en la época en la que escribe Machado, pero que acerca ese tiempo a la actualidad. De allí también que el campo arado dé a una masiva hilera de bloques de apartamentos. En un barrio desarraigado rodeado de la meseta se siente la nada de esta naturaleza tan poco nutriente a muchos niveles. 


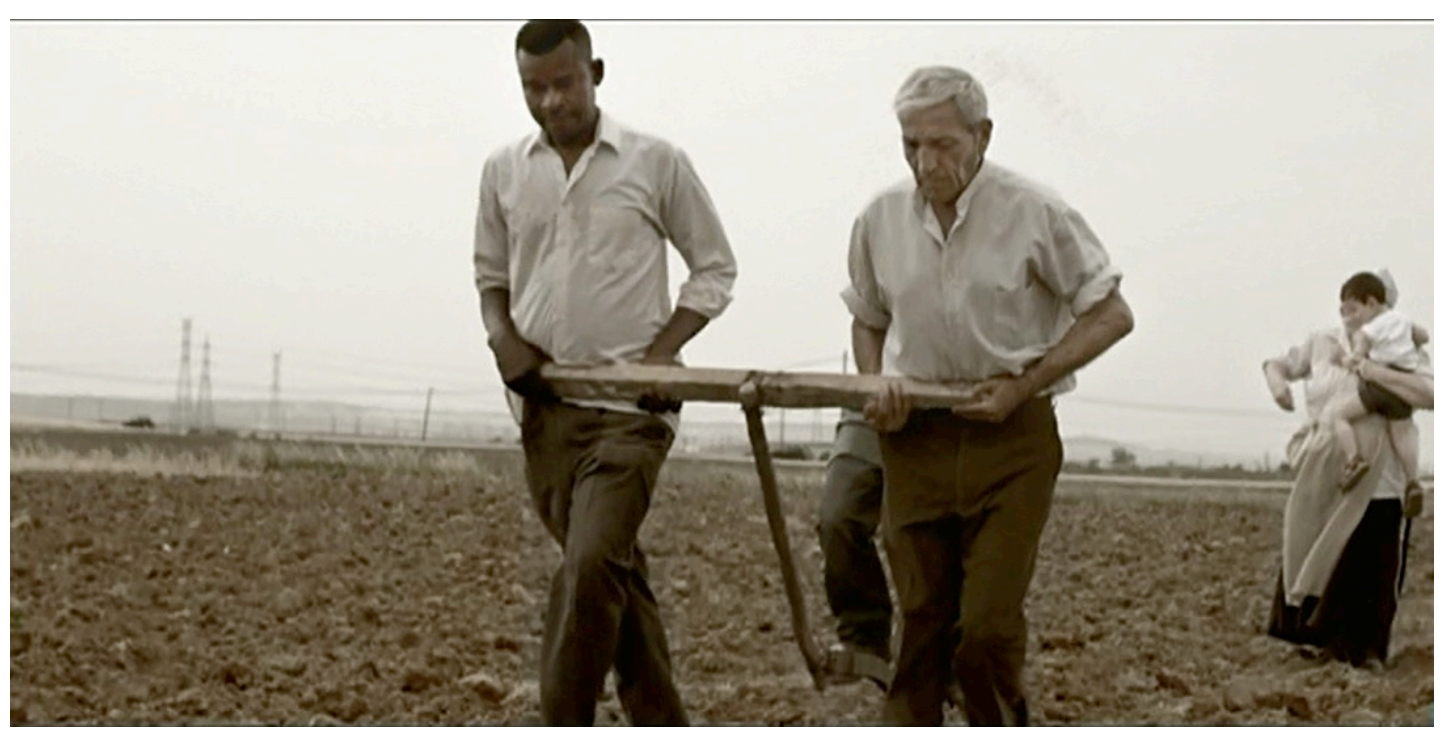

Chapero (Iglesia, 2012) reconoce la crisis de la cultura pero afirma que existe "sí o sí, no puede no existir". Y recuerda que "hay que dejar de ver la cultura como despiezada de la realidad". Machado insta a "esgrimir las armas de la cultura, las armas del amor para comprender". A pesar de su profundidad, Machado ha sido popularizado por la cultura de masas mediante la musicalización de sus versos. En palabras de Chapero-Jackson [fig. 4]:

en su trayectoria poética, Machado hizo un ejercicio de depuración, llevó a cabo lo que él definía autofolclore, es decir, el intento de llegar al otro a través de formas populares, salir del narcisismo y así, desde la sencillez y de lo vivo, llega (...). Con el guiño -un monje nipón leyéndole en japonés- quise mostrar cuán universal es Machado; no se trata sólo de Campos de Castilla, habla de un olmo seco de Castilla pero a la vez habla a todos los árboles secos, y con esa sencillez tan propia de un lugar en las antípodas.

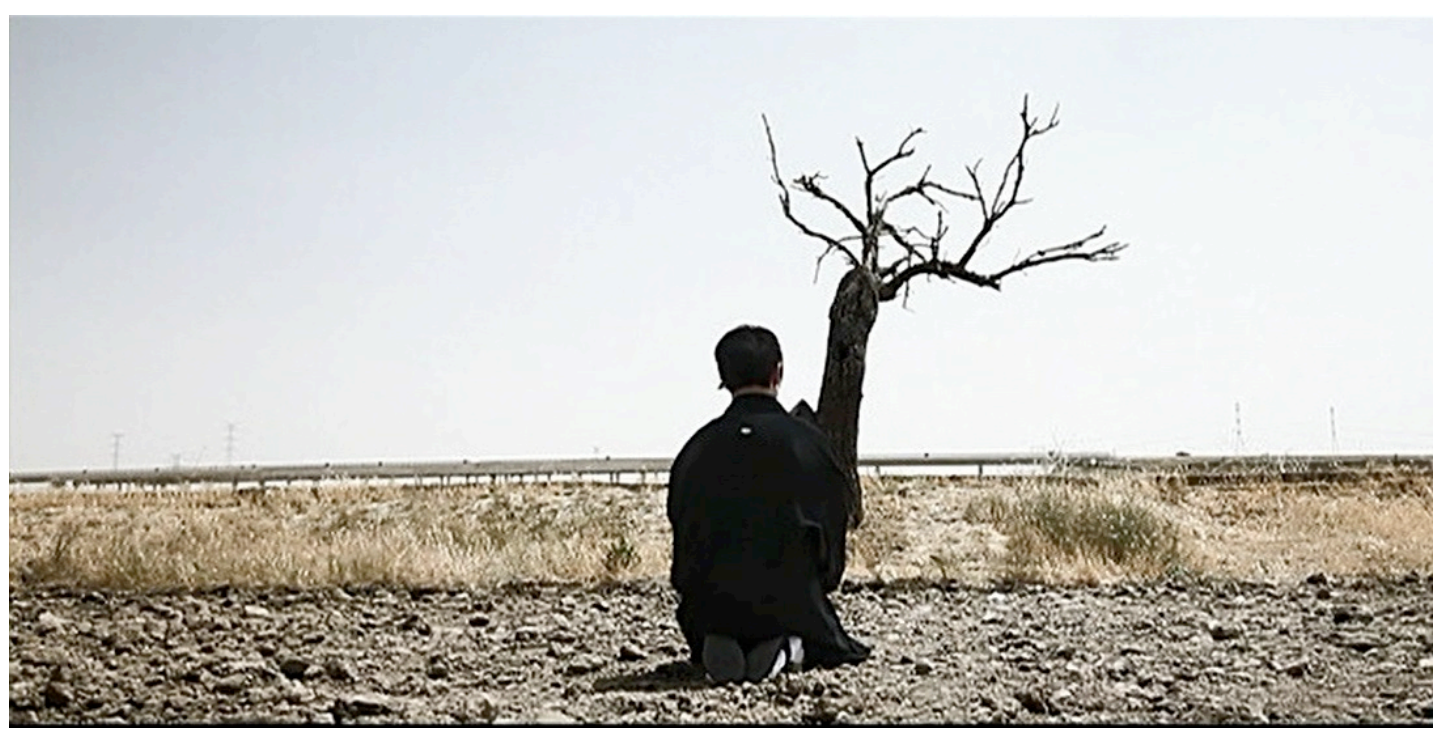

99 
Y afirma también que al releer al poeta Antonio Machado quedó atrapado al sentir que la poesía le hablaba a él: "en el fondo, el cometido de la literatura es enriquecer tu humanidad y tu relación con la vida”. Específicamente, Chapero señala que una idea recurrente en su trabajo es tratar de "revelar aquello que no queremos ver, mostrar aquella zona oscura que no queremos ver y que sin embargo vale la pena ver". Y al respecto del cine, prosigue planteando que se ha posicionado fundamentalmente como entretenimiento pero que también "las grandes películas comerciales" muestran algo no visto: "son espejo de algo hasta entonces desconocido, y al mismo tiempo te asisten con herramientas, ideas que te despiertan, que te permiten tener tu propia brújula y no seguir por inercia, a ciegas. Esto es lo que significa despertar”.

El despertar en la obra de Machado y de Chapero-Jackson es un tema importante reflejado en Los mundos sutiles. Sira, la protagonista, se va identificando a lo largo del documental con la biografía de Machado, al mismo tiempo que va anotando en su cuaderno etapas clave de la vida del poeta que coinciden con la suya propia. Entre ellas se encuentra Despertar, momento que le lleva a afirmar "se baila lo que se pierde" personalizando el verso de Machado "se canta lo que se pierde" [fig. 5], aludiendo a la nostalgia asertiva. Sira es un ejemplo de la idea de percepción que aporta Llorca (2005, p.238), para quien dicha percepción proviene de los procesos de aprendizaje y memoria, “en un contexto de interacción interpersonal”. Esa percepción del entorno y del otro le permitirá al individuo profundizar en su conocimiento. Proceso que sufre Sira según va ahondando en la percepción y reconocimiento de la memoria de Machado.

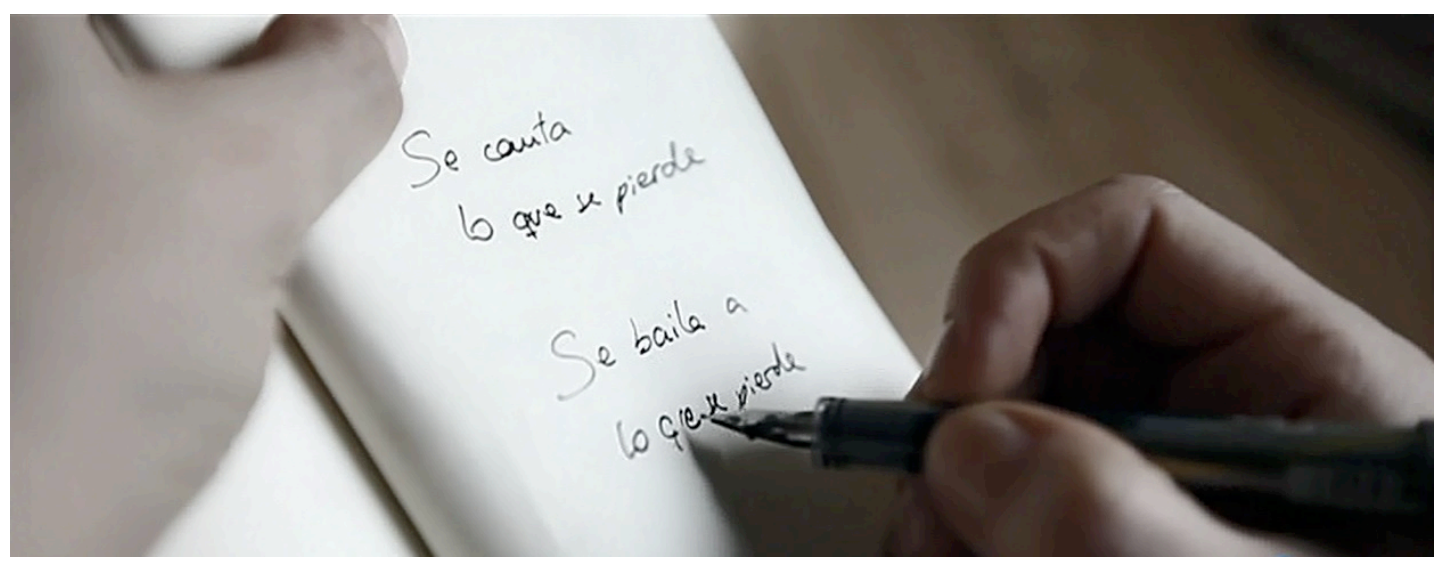


Los mundos sutiles propone mediante la obra de Machado y su contexto socio-político una revisión de la época actual. Chapero-Jackson (Combarros, 2012) confirma la agresividad y la injusticia de la sociedad y contrapone "el deseo de meterse y acunarse en el alma de uno", haciendo referencia al poeta y atribuyéndole una "especie de anhelo por la sutileza y la belleza", y de ahí el título de este documental sacado del poema "Yo amo los mundos sutiles/ingrávidos y gentiles como pompas de jabón”. La referencia a lo sutil implica la necesidad humana de profundizar, de detenerse en lo sensorial, ese elemento que reclama el poeta a medio camino entre el vivir y el soñar, y al que el individuo no debe renunciar.

Los elementos caracterizadores del cine postmoderno, según Zavala (2007, p.137), pueden encontrarse en gran medida en Los mundos sutiles:

En el inicio narrativo de este documental, una niña juega con pompas de jabón mientras una voz en off recita el poema Autorretrato de Antonio Machado, logrando intrigar al espectador aunque se trate de una biografía sobradamente conocida. La autonomía referencial de las imágenes está presente en la simbología de la mayor parte de las escenas, como en el contraste de los campos áridos y los bloques grises de viviendas, o el patio donde Sira baila, o los espacios vacíos donde aparece el fantasma de Leonor [fig. 6], que expresan un sentimiento de soledad y aislamiento. El ritmo de la historia se marca entre la complicidad del sonido, la danza y los sentimientos de los protagonistas. Se cuenta mediante una edición itinerante, recurriendo al pasado a través de imágenes documentales de Machado y su época, pero también de la época contemporánea del director, como las manifestaciones del $15 \mathrm{M}$ en Madrid. Se establecen contrastes visuales entre la ambientación y algunos personajes que intervienen en la historia. Es el caso de la anciana enlutada que camina con dificultad por los campos inertes y desérticos que contrastan con los bloques de viviendas de fondo [fig. 7]. Al término del documental se percibe el simulacro de epifanía del que habla Lauro Zavala, cuando Sira, a pesar de su fracaso puesto que no consigue el papel que quería en la academia de danza, aprende que hay que seguir adelante, como el verso "hoy es siempre todavía", que recoge también la idea postmoderna 
de la falta de límites temporales. La bailarina sin renunciar a sí misma, interpreta en su burbuja transparente su propia visión de Machado.
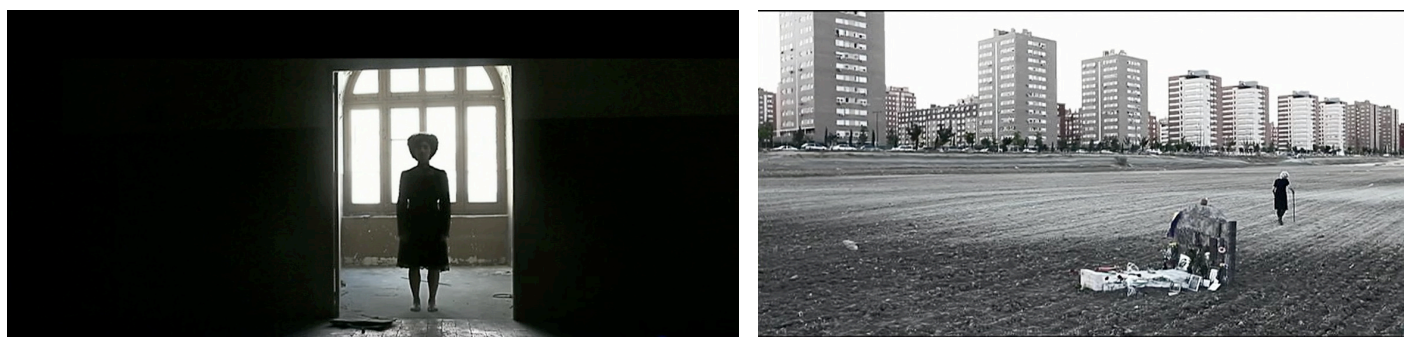

La fusión de géneros postmoderna también está presente en este documental del cineasta Chapero-Jackson (Iglesia, 2012) que confiesa que su trabajo está más cercano a la poesía que a la prosa cinematográfica. Se detecta claramente la fusión de géneros dentro de la literatura, como la mezcla del ensayo y de la poesía, e incluso entre la literatura y otras disciplinas, como literatura y periodismo, literatura y cine, literatura y reportaje; y de la misma manera si hablamos del cine, entre cine tradicional y cine experimental o entre cine y documental, etc. Sobre los referentes utilizados para su documental, Chapero-Jackson (Ibid.) insiste:

me guié mucho por los espacios poéticos y el imaginario de Machado y de cómo podían relacionarse con el imaginario de la protagonista. Me interesó mucho, y creo que es uno de los grandes hallazgos de Machado, la imagen de las galerías del alma: espacios, recovecos, una especie de arquitectura del sueño que enlaza con el subconsciente colectivo. A partir de aquí, busqué espacios afines (...) buscaba una plaza abandonada, un cuadrilátero gris sobre el cual poder hablar de la soledad, del aislamiento... el color gris dice ya de por sí muchas cosas. En verdad, no se necesita mucho aspaviento para crear algo que comunique, en el cine lo poético es peligroso: puede haber un exceso de manierismo, de literariedad...

Frente a la idea despectiva de pastiche en el arte postmoderno, el documental Los mundos sutiles supone una definición clara del estilo personal de Chapero-Jackson marcado por su poética cinematográfica. Esta obra no renuncia a la complejidad, a la búsqueda de significado, a que el espectador se mire dentro, a soñar con los ojos abiertos, siguiendo al poeta Antonio Machado. Y se ofrecen escenas en que danzas ancestrales se funden con las contemporáneas o se interpreta el poema de Las moscas desde una perspectiva más actual. En este documental se precisa un papel activo por 
parte del espectador para que dé sentido a los mensajes propuestos por el cineasta al respecto de Antonio Machado y su obra.

La metanarratividad está reflejada al referenciarse la vida y obra del poeta con un momento concreto de la vida de la bailarina protagonista. Sobre el fragmentarismo, Chapero-Jackson utiliza el mundo onírico de Sira para desarrollar su identificación con Machado. Lo ultrarreal también se hace presente a través de los fantasmas de Machado y Leonor, así como de los espacios que los rodean y las pompas sólidas rojas que contrastan con los espacios y paisajes solitarios, arrasados y quemados [fig. 8]. Si bien en Los mundos sutiles, se puede hablar de esa representación artística de la realidad que menciona Zavala, Chapero-Jackson en su documental se acerca a los rasgos característicos del realismo postmoderno literario español puesto que recurre a un proceso de mímesis alegorizadora, emanada del imaginario personal pero que permite que el lector identifique la realidad. También este guión muestra claramente un proceso de investigación sobre la vida, la obra, así como sobre el contexto sociopolítico de Machado que en la actualidad se identifica con el personaje de Sira. De este modo se logra un análisis de la realidad española contemporánea desde una perspectiva diferente, novedosa, en que la función estética y referencial se hallan en un mismo nivel.

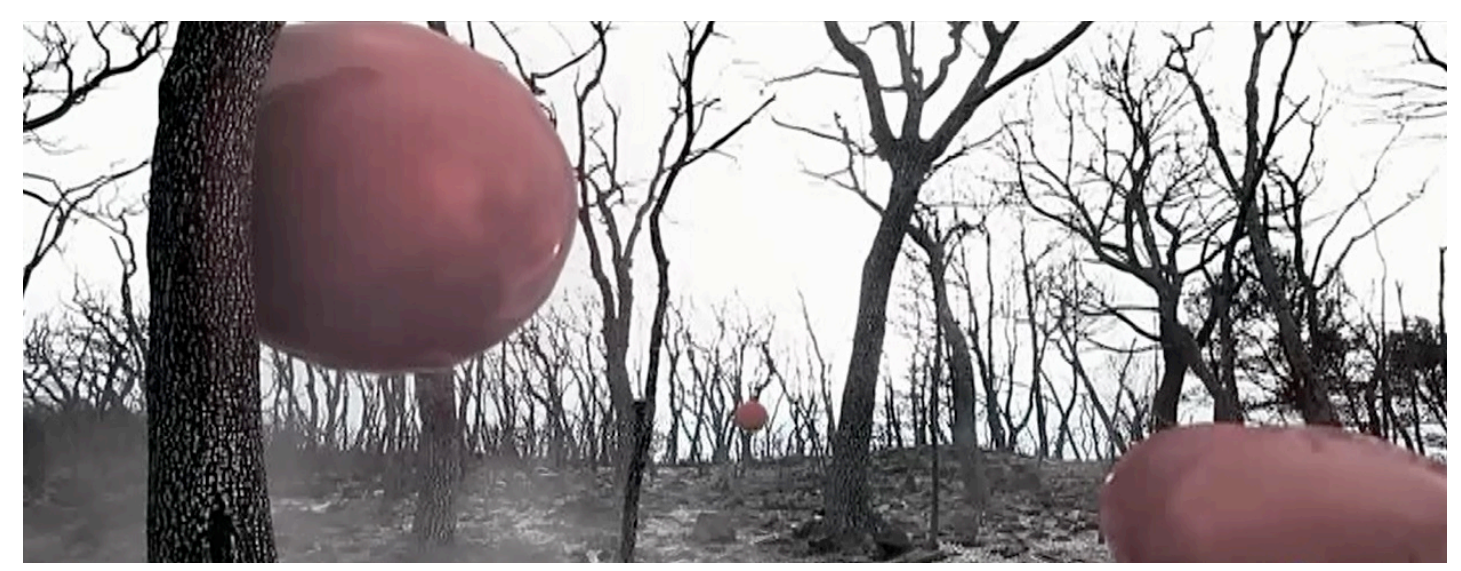

Sobre las temáticas postmodernas del cine, la violencia en Los mundos sutiles resulta visible, por ejemplo, en la imagen de la emanación de la sangre del interior de las tierras áridas [fig. 9]. El vacío de Machado que se hace explícito en la obra de Chapero-Jackson alude a una juventud sin amor que compartirá la protagonista. El predominio de la expresión corporal se plasma 
también puesto que la mayor parte de la historia se narra mediante la danza y la expresión corporal, propiamente. La presencia artística de esa relación entre cuerpo, muerte y violencia, se produce en la escena del paso procesional viviente que avanza al ritmo de una saeta y en el que se representa mediante la danza, el dolor de Machado ante la muerte de Leonor [fig. 10]. La clasificación de no lugares a que se refiere Imbert (a) 2010, pp.253-254) se localiza con no lugares físicos como la noche, los paisajes solitarios, desérticos o interiores de viviendas abandonadas, desvencijadas; $\mathrm{y}$, por otro, los simbólicos, como el sueño, en los que la presencia de eros y thanatos se entremezclan junto a la soledad del individuo. En este documental, frente a espacios donde el individuo no deja huella, Machado lo hace con su poesía del presente "se hace camino al andar". Con el último verso del poeta "Estos días azules y este sol de la infancia", que se transmite de generación en generación al término de esta obra del cineasta ChaperoJackson, Machado pervive por el carácter transfronterizo de su poesía.

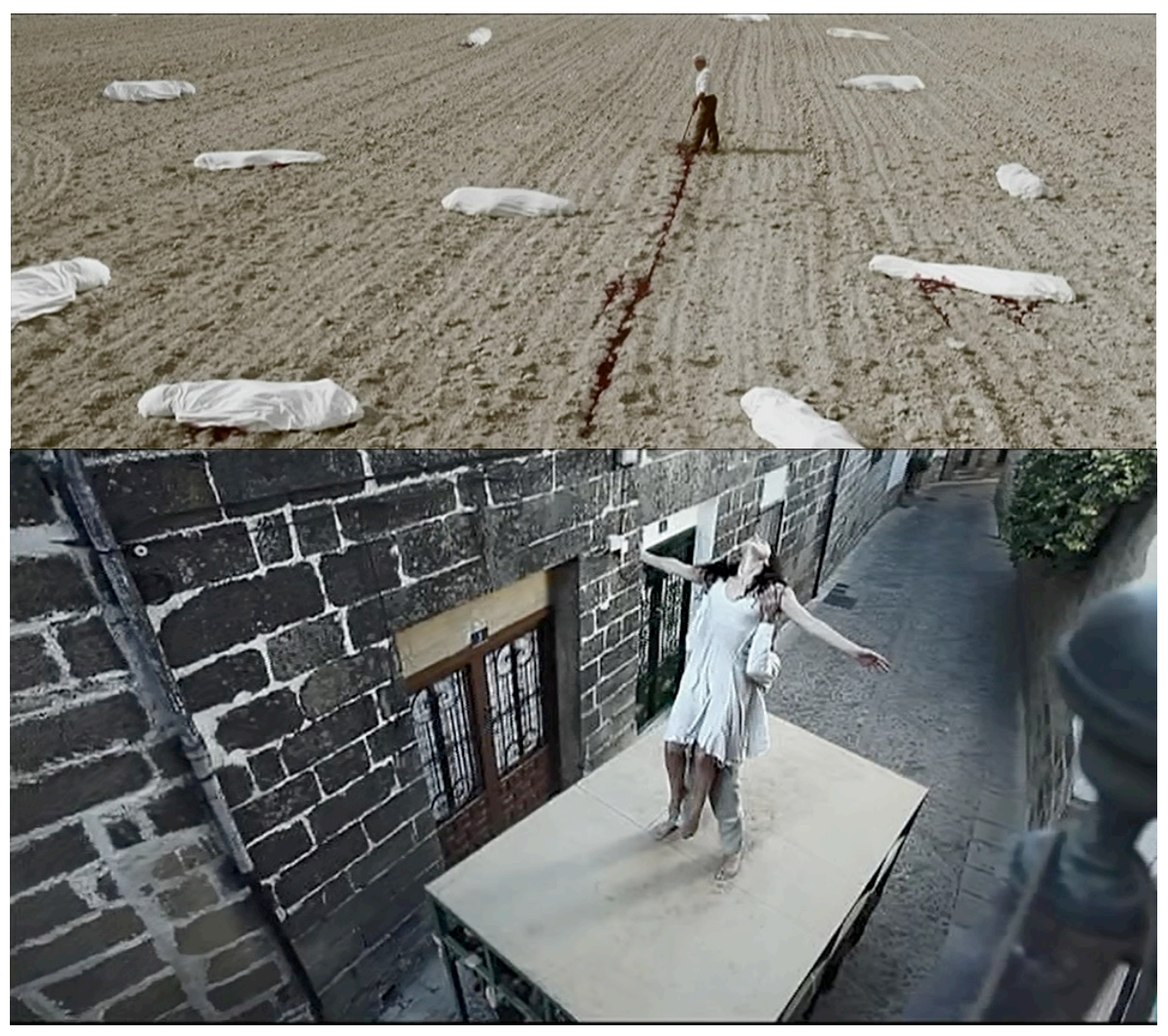




\section{Conclusión: papel del cine postmoderno en la crisis de la postmodernidad}

Lyotard (1987, pp.111-112) reconoce el papel responsable del arte, resistiendo y testimoniando. El arte como resistencia. El cine como resistencia, como provocador, con el objetivo de cuestionar a la sociedad postmoderna, en este caso. Cine de calidad como generador de imaginarios que ayuden al espectador a entender su presente $\mathrm{y}$, por lo tanto, a la propia crítica cinematográfica para que mejore su credibilidad. Con este artículo quiere contribuirse a cómo interpretar la potencia crítica de estos creadores cinematográficos, su papel de analistas en los problemas sociales..., su responsabilidad frente a la carencia de ideas, de conflictos éticos, a la falta de complejidad y coherencia en las estructuras cinematográficas, ante el asedio del marketing que obliga a crear según las exigencias del mercado renunciando a la calidad. Características todas que se achacan a la postmodernidad.

Los mundos sutiles de Chapero-Jackson supone un análisis de la realidad española contemporánea desde una perspectiva diferente y novedosa. Esta obra cinematográfica genera imaginarios, aunando poesía, danza y cine en favor del diálogo, de la recuperación de la identidad, de una visión global de los acontecimientos recurriendo a un paralelismo con situaciones pasadas, frente a un positivismo y un nihilismo radicales. En contra de la crisis social y personal que afecta a la sociedad actual, se reivindica una cultura integrada en la realidad social, una revisión de la época postmoderna en que el ser humano profundice, ahonde en el interior de sí mismo, despierte..., sin renunciar a lo sensorial, siguiendo al poeta Antonio Machado.

Se trata de reivindicar el cine en la crisis de la postmodernidad y el postmodernismo cultural. En un mundo global, qué dice el cine sobre el mismo mundo y sobre sí mismo como fenómeno cultural que influye en la percepción de las personas y en la reconfiguración de sus expectativas, siguiendo a Lipovetsky y Serroy (Esteban, 2013, p.27). El cine como fenómeno que contribuye al desarrollo sociocultural. "No proclaméis la 
libertad de volar sino dad alas, no la de pensar sino dad pensamiento...”, insistía Unamuno.

\section{Referencias bibliográficas}

Barbancho, I. (2011). Mundos perdidos. Una aproximación tematológica a la novela postmoderna, 1980-2005. Madrid: CSIC.

Beriain, J. (2008). Aceleración y tiranía del presente. Barcelona: Anthropos.

Beriain, J. (2007). Introducción: modernidad, barbarie y violencia colectiva. Papers, 84, 7-18.

Best, S.; Kellner, D. (1991). Postmodern Theory. Critical Interrogations. New York: Guilford Press.

Calinescu, M. (2003). Cinco caras de la modernidad. Madrid: Tecnos y Alianza Editorial.

Carretero, A. E. (2003). Postmodernidad e imaginario. Una aproximación teórica. Foro Interno, 3, 87-101.

Civila de Lara, E. (2013). Aproximación al cine postmoderno: las maneras de hacer mundos de Jim Jarmusch, en: http://huespedes.cica.es/aliens/gittcus/edu.html

Combarros, C. (2012): “57 Seminci-Eduardo Chapero-Jackson: "La naturaleza humana es la materia prima de lo que hago, contar historias para intentar entender cómo funcionamos". Agencia de Noticias de Castilla y León (ICAL). 24 de octubre de 2012

Elías, C. (2008). La razón estrangulada. La crisis de la ciencia en la sociedad contemporánea. Barcelona: Debate

Esteban, J. L. (2013). El imaginario cinematográfico y la sociedad hipermoderna. Valladolid: Universidad Europea Miguel de Cervantes.

Fernández, J. (2010). El “post” de la postmodernidad. Una poética postmodernista, en: http://serbal.pntic.mec.es/AParteRei

Gómez, A. (2012). Entre el collage y el bricolaje. Una cierta mirada hacia El desprecio de Godard en Los abrazos rotos de Almodóvar. Fotocinema, $5,76-93$.

Gordon, J. (2013). Modernismos y cine después de la postmodernidad: el caso de Wong Kar Wai. Razón y palabra, 84, en http://www.razonypalabra.org.mx/N/N84/V84/24_Gordon_V84.pdf

Iglesia, A. M. (2012). En el cine lo poético es peligroso", en http://www.revistadeletras.net/eduardo-chapero-jackson-en-el-cinelo-poetico-es-peligroso/ 
Imbert, G. (2002). Azar, conflicto, accidente, catástrofe: figuras arcaicas en el discurso posmoderno (entre lo eufórico y lo disfórico). Trama y fondo: revista de cultura, 12, 19-30.

Imbert, G. (2004). De lo espectacular a lo especular (apostilla a la Sociedad del Espectáculo). Cuadernos de Información y comunicación, 9, 103121.

Imbert, G. (2010). a) Cine e imaginarios sociales. Madrid: Cátedra.

Imbert, G. (2010). b) La sociedad informe. Postmodernidad, ambivalencia y juego con los límites. Barcelona: Icaria.

Imbert, G. (2013). Cine e imaginarios sociales. En Esteban, J. (Ed.), El imaginario cinematográfico y la sociedad hipermoderna (pp.15-22). Valladolid: Universidad Europea Miguel de Cervantes.

Lipovetsky, G. y Serroy, J. (2010). La cultura-mundo. Respuesta a una sociedad desorientada. Barcelona: Anagrama.

Llorca, G. (2005). (In)comunicación y arquitectura. Paul Virilio: Claves para un debate. Comunicación, 3, 235-251.

Llorca, G. (2010). Comunicación, aceleración y realidad. En Ciclo de Debate sobre la Aceleración Velocidad, Cultura y Comunicación en los Espacios Urbanos Contemporáneos. Universidad Europea Miguel de Cervantes y Museo de Arte Contemporáneo: Patio Herreriano de Valladolid. 14 de abril de 2010

Lyon, D. (2000). Postmodernidad. Madrid: Alianza editorial.

Lyotard, J-F. (1987). La posmodernidad. Barcelona: Gedisa.

Muñoz de Baena, J. L. (2011). Tiempo y literatura en la industria cultural. En Esteban J. (Ed.), Palabra y ficción. Literatura y pensamiento en tiempo de crisis cultural (pp.131-144). Valladolid: Universidad Europea Miguel de Cervantes.

Murcia, I. (2009). Copiar o crear. La postmodernidad desde el cine de Michelangelo Antonioni y Brian de Palma. Rev. AISTHESIS, 45, 103121.

Navajas, G. (1993): Una estética para después del posmodernismo: la nostalgia asertiva. Revista de Occidente, 143, 105-130.

Navajas, G. (2008). La utopía en las narrativas contemporáneas (Novela/Cine/Arquitectura). Zaragoza: Universidad de Zaragoza.

Peña-Ardid, C. (2009). Literatura y cine. Madrid: Cátedra.

Rodríguez Pastoriza, F (2006). Periodismo cultural. Madrid: Síntesis.

Thibaudeau, P. (2013). El cuerpo, la piel y la pantalla: los territorios habitados por Pedro Almodóvar. Fotocinema. Revista científica de cine y fotografía, $7,192-208$.

Zamora, J. (2005). Ciencia pública-ciencia privada. Reflexiones sobre la producción del saber científico. México: Fondo de cultura económica. 
R. Ma Arráez Betancort y C. Pascual Pérez La crisis de la postmodernidad: análisis textual de Los mundos sutiles de Chapero Jackson

Zavala, L. (2007). La ficción posmoderna como espacio fronterizo. Ciudad de México: (Tesis. Centro de estudios Lingüísticos y Literarios), en: http://www.sepancine.mx/attachments/Lauro_Zavala 